\title{
THE REVIEW OF RUSSIAN ECONOMIC LEGISLATION IN JULY 2015 ${ }^{1}$
}

\author{
I.Tolmacheva, Yu.Grunina
}

In July, the following main amendments were introduced into the legislation: the periods of re-issuing of the license to carry out educational activities and the certificate of state accreditation have been extended; resources of funds for support of scientific, $R \& D$ and innovation activities along with federal budget funds have been attributed to the main funds of financing of fundamental and exploratory research; a law on activities of credit rating agencies was approved in Russia.

\section{Federal Laws of the Russian Federation}

1. Federal Law No.238-FZ of 13 July 2015 on AMENDMENT OF THE FEDERAL LAW ON EDUCATION IN THE RUSSIAN FEDERATION

Earlier, the period of re-issuing of a license to carry out educational activities and the certificate of state accreditation was set till 1 January 2016. At present, it has been extended till 1 January 2017.

Also, it has been determined that as regards an institution which carries out educational activities and was reorganized through affiliation to it of another educational institution, a temporary certificate of state accreditation is reissued for the certificate of state accreditation for the period till the end of validity of the certificate of state accreditation which was earlier issued to the reorganized institution.

The period of enrollment of winners of Academic Olympics without entrance exams to higher education establishments has been changed. Now they may use that right within four years following the year of the Academic Olympics.

2. Federal Law No. 270-FZ of 13 July 2015 on AMENDMENT OF THE FEDERAL LAW ON SCIENCE AND STATE R\&D POLICY AS REGARDS UPGRADING OF FINANCIAL INSTRUMENTS AND MECHANISMS OF SUPPORT OF SCIENTIFIC AND R\&D ACTIVITIES IN THE RUSSIAN FEDERATION

New definitions have been introduced into Article 2 of Federal Law No.127-FZ of 23 August 1996 on Science and State R\&D Policy. In particular, it has been defined that a scientific project or R\&D project is a complex of well-coordinated measures aimed at receiving scientific and R\&D outputs and fulfillment of that work is limited by a time period and the amount of funds raised. Also, the definition of the center for collective use of research equipment and unique research installation was introduced. From now on, research institutions may establish centers for collective use of research equipment and unique research installations.

1 The Review was prepared with assistance of the KonsultantPlus Legal System.
It has been determined that the main source of funding of fundamental and exploratory research are federal budget funds, as well as funds of support of scientific, R\&D and innovation activities.

Funds facilitating scientific, R\&D and innovation activities are established for the purpose of funding scientific, R\&D and innovation activities, including on the terms of co-financing at the expense of funds of different sources which are not banned by the legislation of the Russian Federation.

The above funds may be established by the Russian Federation, constituent entities of the Russian Federation, individuals or legal entities in the corporate form of a fund.

To achieve its goals, the fund facilitating scientific, $R \& D$ and innovation activities is entrusted with the following functions:

- development of lines of research or pilot projects facilitated by such a fund;

- selection on a tender basis of scientific and R\&D programs and projects, and innovation projects, including those aimed at long-term development of research entities and higher education establishments;

- carrying out of due-diligence of scientific and R\&D programs and projects and innovation projects which are completely or partially funded by means of such a fund in carrying out of selection on a tender basis and at all the stages of fulfilment of the above programs and projects;

- funding of scientific, R\&D programs and projects and innovation projects mainly by means of grants extended to individuals and legal entities for implementation of above programs and projects;

- carrying out of control over the efficiency of scientific and R\&D programs and projects and innovation projects which are financed by such a fund at all the stages of implementation of those programs and projects; 
- provision of the information on its activities;

- fulfilment of other functions determined by the founder in establishing of such a fund.

3. Federal Law No.222-FZ of 13 July 2015 on ACTIVITIES OF CREDIT RATING AGENCIES IN THE RUSSIAN FEDERATION, ON AMENDMENT OF ARTICLE 76.1 OF THE FEDERAL LAW ON THE CENTRAL BANK OF THE RUSSIAN FEDERATION (BANK OF RUSSIA) AND RECOGNITION AS NULL AND VOID OF INDIVIDUAL PROVISIONS OF STATUTORY ACTS OF THE RUSSIAN FEDERATION

The federal law has established fundamental legal principles of credit rating agencies assessing the ability of legal entities and public-law entities to fulfill their financial obligations and credit risks related to financial liabilities and instruments of such entities, as well as the authorities of the Central Bank of Russia in carrying out of regulation and supervision in the field of activities of credit rating agencies. Also, the above law is aimed at protection of the rights and legal interests of persons who are assigned a credit rating to and users of credit ratings, including creditors and investors and ensuring of transparency and independence of credit rating agencies' activities.

The law provides a definition of a credit rating agency: it is a legal entity established in the form of incorporation in accordance with the legislation of the Russian Federation, entered by the Central Bank of Russia in the register of credit rating agencies in accordance with the requirements the above federal law and carrying out rating-related activities. It is to be noted that a requirement to the size of the own capital in the amount of minimum $\mathrm{Rb} 50 \mathrm{~m}$ was set.

The uniform rules of activities, including the requirement to be independent from any political and economic influence, prevent conflicts of interests and disclose the information on the activities of rating agencies were determined.

Requirements to the activities of international and national rating agencies have been introduced and the specifics of utilization of ratings assigned in accordance with the international and national rating scales were determined.

Also, the law provides for the mechanisms of supervision and control over the activities of rating agencies. The authorities of the Central Bank of Russia as regards approval of the procedure for and fulfillment of accreditation of rating agencies, keeping of the register thereof, carrying out of audit, consideration of complaints and applications related to the activities of rating agencies and keeping record of the assigned ratings were determined. 